\title{
Reducing discards in trammel net fisheries with simple modifications based on a guarding net and artificial light: contributing to marine biodiversity conservation
}

\author{
Pedro Martínez-Baños ${ }^{1}$, Francesc Maynou ${ }^{2}$ \\ ${ }^{1}$ C\&CMedioambiente, Antonio Oliver 17, Ed. Spica, 30204 Cartagena, Spain. \\ (PM-B) E-mail: pedro@cycmedioambiente.com. ORCID iD: http://orcid.org/0000-0002-7546-9263 \\ ${ }^{2}$ Institut de Ciències del Mar, CSIC. Pg. Marítim de la Barceloneta 37-49, 08003 Barcelona, Spain. \\ (FM) (Corresponding author) E-mail: maynouf@icm.csic.es. ORCID iD: http://orcid.org/0000-0001-7200-6485
}

\begin{abstract}
Summary: Experimental fishing trials with standard (control) and modified trammel nets were conducted to assess the possible reduction of discards. The standard trammel net was the commercial net used in the area $(80 \mathrm{~mm}$ stretched mesh inner panel) targeting Sepia officinalis. This configuration produced $19 \%$ discards in weight. The modifications researched were of two kinds: a "guarding net" consisting of a 2.5-mesh-high (200 $\mathrm{mm}$ stretched mesh) net between the footrope and the trammel net and artificial lights of two colours (white or green) mounted on the floating ropes. Catches were identified, measured and categorized (commercial, discards and reason for discarding), and the different configurations were tested for statistical differences. Our results show that trammel net deployments with guarding net produce $32 \%$ higher catches of commercial species and as much as 95\% higher catches of the target cuttlefish. Artificial lights produced a low but significant increase in total catches of commercial species of $13 \%$, with no differences due to light colour. The amount of discards in deployments with guarding net was $6 \%$, i.e. $c a .1 / 4$ of the amount produced by the standard configuration. The effect of lights on discard reduction was not significant.
\end{abstract}

Keywords: experimental fishing; discard reduction; trammel net fisheries; Mediterranean Sea; cuttlefish.

Reducción de descartes en pesca de trasmallo mediante modificaciones simples basadas en el ajuste de un faldón y luz artificial: una contribución al mantenimiento de la biodiversidad marina

Resumen: Se llevaron a cabo pescas experimentales con trasmallos estándar (control) y modificados para evaluar la posible reducción de descartes. El trasmallo estándar empleado fue el trasmallo comercial que se usa habitualmente en la zona (paño interior de $80 \mathrm{~mm}$ de malla estirada) que tiene por objetivo la sepia Sepia officinalis. Esta configuración produjo 19\% de descartes en peso. Las modificaciones investigadas fueron de dos tipos: el ajuste de un faldón en la parte inferior del trasmallo de 2.5 mallas de alto ( $200 \mathrm{~mm}$ malla estirada) y luz artificial de dos colores (blanca o verde) colocadas en la relinga de flotadores. Se identificaron, midieron y categorizaron (comercial, descartes y razones del descarte) las capturas y se evaluaron estadísticamente las diferencias debidas a las distintas configuraciones. Los resultados indican que el trasmallo con faldón produjo un incremento del $32 \%$ en las capturas comerciales, y en el caso de la sepia un $95 \%$ más elevadas. La luz artificial produjo un aumento débil, pero significativo, en el volumen de capturas totales de $13 \%$, sin diferencias debidas al color empleado. Los descartes en trasmallos con faldón fueron del $6 \%$ (es decir, cerca de una cuarta parte de la cantidad producida en la configuración estándar). El efecto de las luces sobre la reducción de los descartes no fue significativa.

Palabras clave: pesca experimental; reducción descartes; pesca con trasmallo; mar Mediterráneo; sepia.

Citation/Como citar este artículo: Martínez-Baños P., Maynou F. 2018. Reducing discards in trammel net fisheries with simple modifications based on a guarding net and artificial light: contributing to marine biodiversity conservation. Sci. Mar. 82S1: 9-18. https://doi.org/10.3989/scimar.04710.03A

Editor: M. Demestre.

Received: September 14, 2017. Accepted: March 14, 2018. Published: May 18, 2018.

Copyright: () 2018 CSIC. This is an open-access article distributed under the terms of the Creative Commons Attribution 4.0 International (CC BY 4.0) License. 


\section{INTRODUCTION}

The coastal small-scale fisheries practised in southern European waters employ mainly set nets as fishing gear (trammel nets and, to a lesser extent, gillnets and longlines) (Stergiou et al. 2006). Given the low economic performance of small-scale fisheries in Europe and their importance as a producer of high-quality fresh seafood of local origin (Griffiths et al. 2007, Guyader 2007), technical measures promoting their viability without increasing their impact on fisheries resources or habitats need to be introduced (Gonçalves et al. 2007, Maynou et al. 2011). Among these, the reduction of unwanted catches in small-scale fisheries can reduce maintenance and operational costs for fishermen as well as the impact on benthic communities.

Unwanted by-catch is relatively low in Mediterranean fisheries using set nets compared with that of fisheries using towed gears. In set nets, the mesh sizes employed are usually large enough to guarantee compliance with minimum landing sizes for most species (Erzini et al. 2006), while in longlines the selectivity can be reasonably controlled by the choice of hook size. However, discarding of unwanted by-catch or damaged commercial specimens is frequent and represents a cost for fishers (Gonçalves et al. 2008). Additionally, damaged commercial catches cannot be commercialized and represent a loss of income (Rossetti et al. 2006).

South European small-scale fisheries using set nets can have discards of $15-25 \%$ of the total catch (EC 2002). However, Gonçalves et al. (2008) report discards of $50 \%$ and estimate that the trammel net may be the main fishing gear in terms of ecological impact on benthic communities in the coastal zone, due to its widespread use and relatively high proportion of discards compared with other small-scale fishing gear. On the other hand, Rossetti et al. (2006) showed that large amounts of unwanted catches (non-commercial crabs or gastropods) reduced the economic profitability of the caramote prawn (Penaeus kerathurus) fishery in the Ligurian and Tyrrhenian sea due to the extended sorting times and shortened duration of the fishing gear.

The EU discards ban, or Landing Obligation, published in Art. 15 of EC Regulation 1380/2013 (EC 2013), was aimed at reducing discards in EU fisheries and working towards more selective fishing by incentivizing the adoption of technical solutions and other changes in fishing practices. The discards ban aims at rationalizing the fishing process by means of more selective gears and sustainable practices, which would ultimately result in more productive fisheries (Gullestad et al. 2015).

Improving size or species selectivity of trammel nets is difficult because of the different modes of capture currently encountered in trammel nets (entangling, gilling, wedging and pocketing), which depend on the species caught (Erzini et al. 2006). Among the possible solutions that can be applied to reduce unwanted catches in static nets are modifications to the inner mesh size or the hanging ratio, fitting an extra panel of non-fishing net to minimize the impact of scaveng- ing organisms, using visual or acoustic cues to repel unwanted by-catch, and avoiding fishing grounds with potentially high unwanted catches. Testing modifications to the standard designs based on changes to mesh sizes and hanging ratios is a favoured solution to enhance trammel net selectivity, but will be beneficial for a limited number of species only. Modifications to the existing fishing gear that preclude the access of scavenging organisms to the fishing gear can be a solution to mitigate the problem of excessive unwanted catches damaged by scavengers. For instance, the guarding net has been successfully trialled in different areas of the Mediterranean (Sartor et al. 2007, Metin et al. 2009), and it has been shown to be an effective bycatch reduction device with low impact on sea bottoms. A guarding net is a piece of single net from 10 to 30 $\mathrm{cm}$ high positioned on the lower part of the trammel net panels to produce a physical barrier to climbing scavengers that might damage the capture (Metin et al. 2009, Rossetti et al. 2006).

The objectives of this study were to evaluate the effect of two modifications made to a professional trammel net, a) a guarding net fitted to the footrope and b) artificial lights fitted to the head rope, in terms of reduction of unwanted by-catch, catch of commercial species and undersize specimens.

\section{MATERIALS AND METHODS}

\section{Investigated fisheries}

Small-scale fisheries in the Murcia Region (SE Spain) are carried out by a large number of vessels (129 licensed units in 2016 or $72 \%$ of the local fleet: General Directorate of Agriculture and Fisheries, Region of Murcia) with length overall (LOA) between 6 and 13 $\mathrm{m}$ (engine power 50-100 hp) operated by a crew of two or three persons. The main fishing gears deployed during the year are trammel nets, gillnets and boat seines used to catch a variety of demersal resources. The fleet rotates the métiers practised during the year, depending on the availability of the main target species. In the case of trammel nets, the métiers are defined by the target species: for instance, in winter and spring the target species is the cuttlefish (Sepia officinalis), but it changes to finfish in summer and to striped red mullet (Mullus surmuletus) in late autumn and early winter. The fishing activity with trammel nets is carried out close to home ports, with daily fishing trips of less than $12 \mathrm{~h}$. The trammel nets employed by this fishery are made of 50-m sheets for a total length of 1500 to 2000 $\mathrm{m}$, and they are 1.5 to $2.5 \mathrm{~m}$ high.

\section{Experimental setup}

Two local fishing boats practising the cuttlefish métier were used to carry out the experiments with the modified trammel nets. In the first boat (coded "SP") two trammel nets of $1500 \mathrm{~m}$ length and $1.6 \mathrm{~m}$ high with the same technical characteristics were employed (inner panel $80 \mathrm{~mm}$ nylon (polyethylene) mesh, 40 meshes high; outer panel $200 \mathrm{~mm}$ nylon mesh, 8 

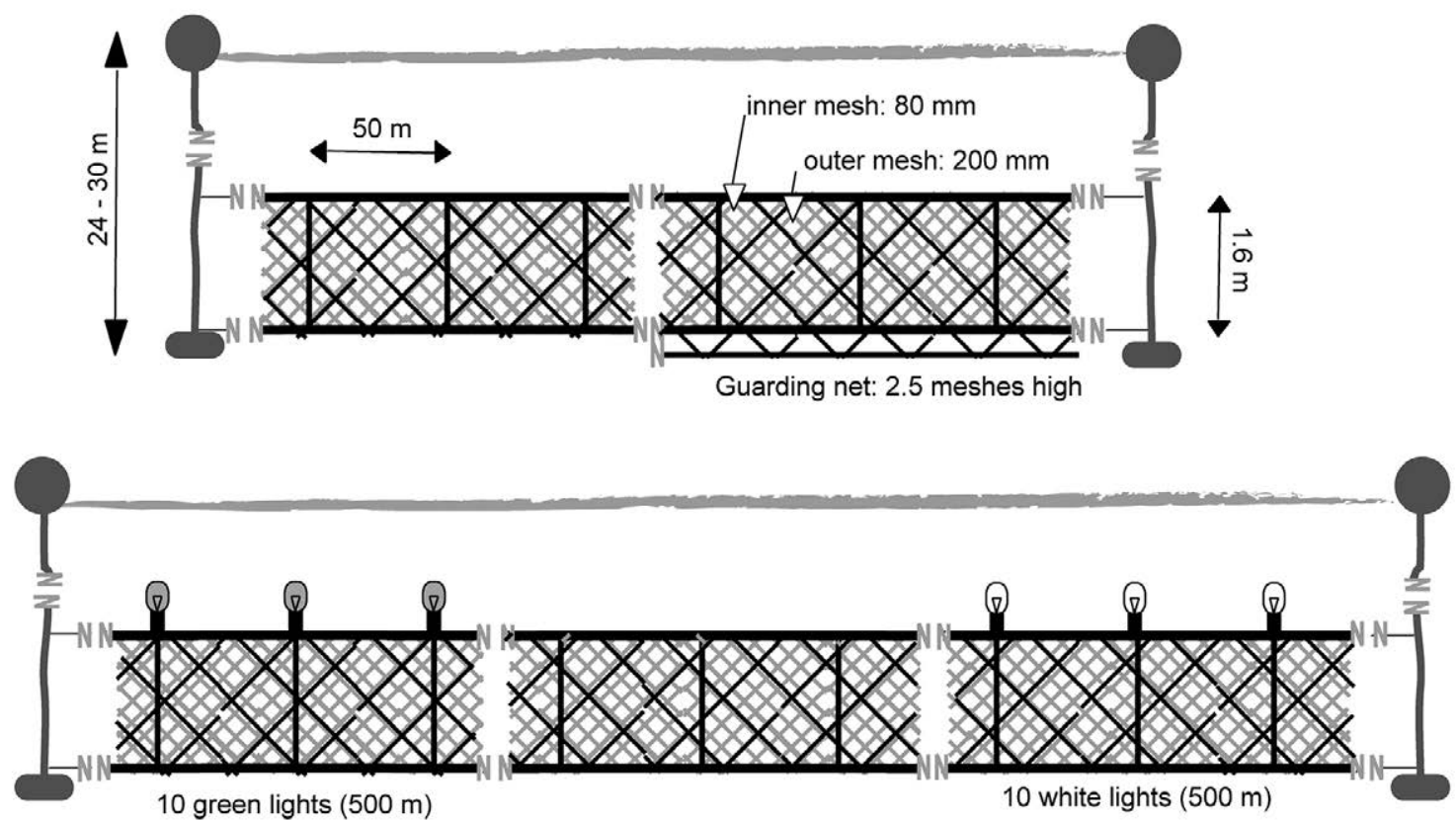

Fig. 1. - Schematic design of the trammel nets used in the experiments. Each trammel net was built of 30×50-m panels (total length $1500 \mathrm{~m}$ ) with a vertical span of approximately $1.6 \mathrm{~m}$, using $80-\mathrm{mm}$ inner meshes and $200-\mathrm{mm}$ outer meshes. The control trammel net is shown in the top left figure. The modified trammel net with a guarding net was created by adding 2.5 meshes (of the external type, i.e. 200 mm) between the footrope and the panel (top right). In the second experimental trammel net, the net was divided into $3 \times 500-\mathrm{m}$ sections ( 10 panels each). Two of the sections were fitted with green or white lights every $50 \mathrm{~m}$ and one section was left unmodified. The position of the three sections along the net was randomized from one day to another during the experiment.

meshes high; hanging ratio 0.82) following the usual professional configuration. One trammel net (the experimental one) was fitted with a guarding net made of 2.5-mesh-high polyethylene mesh $(200 \mathrm{~mm}$, twine thickness $4.2 \mathrm{~mm}$ ) and positioned between the trammel net and the footrope (weighed rope $10 \mathrm{~mm}$ diameter). The other trammel net was employed without modification and served as a control (Fig. 1). From 2 to 23 March 2017, the two fishing gears were set on sandy bottoms between 24 and $30 \mathrm{~m}$ depth at approximately 7 p.m. and were recovered the following day at around 9 a.m. The second experiment was carried out concurrently with the first: a standard trammel net was divided into three sections of $500 \mathrm{~m}$ each. Two sections were provided with artificial lights fixed on the floatline (12 $\mathrm{mm}$ float nylon rope): one section was provided with white lights, the other with green lights (Fig. 1). The artificial lights were units employed in tuna longlining fisheries, commercialized as "LED fishing light, deep sea drop light" manufactured by Ningbo Solars Lighting Electrics (Zhejiang, China). Each unit used two AA batteries whose duration in the laboratory was in excess of one week (nominal manufacturer's specification $300 \mathrm{~h}$ ), but the batteries were replaced every two days in each unit to avoid decreasing light intensity. The position of the three sections along the trammel net was changed randomly in each fishing operation to randomize the effect of light position. The second fishing vessel (coded "AG") only carried out the part of the experiment testing artificial lights from 10 April to 16 May 2017.

Each experimental setup was fished on ten consecutive days, on the basis of operational constraints due to weather conditions and permitted working days. For each fishing operation, the entire catch was analysed for species composition (number and weight). Non-commercial organisms were classified in three categories, D, K1 and K2, where "D" are undersize specimens of commercial species (e.g. belonging to species included in Annex III of EU Reg. 1967/2006 and therefore included in the Landing Obligation provisions), "K1" are damaged specimens of legal size that cannot be commercialized, and "K2" are marine organisms without commercial interest (usually epifaunal invertebrates). The most abundant commercial species were also measured [mantle length (ML) in $\mathrm{cm}$ for cuttlefish; total length (TL) in cm for fishes].

Catch data were standardized in number or weight per $100 \mathrm{~m} \mathrm{~h}$ (soaking time). The commercial species were analysed on the basis of standardized weight data because the possible benefits of using the experimental fishing gear will be assessed by fishers as increases in catch in weight (or in economic value). Conversely, the metric used for discards was standardized number of individuals because trammel net fishers sort the catch specimen by specimen and any reduction of unwanted catches should appear as a reduction in the number of unwanted specimens to be sorted. The immediate expected benefit of the modifications should be reduced sorting time.

\section{Statistical analyses}

The standardized catch rates in weight of commercial species $(\mathrm{kg} / 100 \mathrm{~m} \mathrm{~h})$ were compared by means of linear mixed models using the treatment as a fixed factor (green light, white light, no light) and the boat as a random factor. The assessment of the effect of 
Table 1. - Standardized catch $(\mathrm{kg} / 100 \mathrm{~m} \mathrm{~h})$ and frequency of occurrence of commercial species caught by each net configuration adopted in this study. The 20 most important species in weight are highlighted in bold face.

\begin{tabular}{|c|c|c|c|c|c|c|}
\hline Species & $\mathrm{kg} / 100 \mathrm{~m} \mathrm{~h}$ & frequency of occurrence $(\%)$ & control & guarding net & green lights & white lights \\
\hline Sepia officinalis & 1.43 & 100 & 0.73 & 2.33 & 1.71 & 1.40 \\
\hline Dardanus arrosor & 0.17 & 53 & 0.12 & 0.02 & 0.17 & 0.30 \\
\hline Bolinus brandaris & 0.10 & 49 & 0.05 & 0.01 & 0.08 & 0.23 \\
\hline Uranoscopus scaber & 0.26 & 47 & 0.21 & 0.53 & 0.20 & 0.24 \\
\hline Pagellus erythrinus & 0.33 & 46 & 0.17 & 0.70 & 0.36 & 0.27 \\
\hline Sparus aurata & 0.29 & 46 & 0.16 & 0.24 & 0.21 & 0.58 \\
\hline Hexaplex trunculus & 0.04 & 44 & 0.03 & 0.02 & 0.04 & 0.06 \\
\hline Pagellus acarne & 0.08 & 44 & 0.03 & 0.07 & 0.13 & 0.12 \\
\hline Dentex dentex & 0.44 & 36 & 0.10 & 0.87 & 0.25 & 0.83 \\
\hline Scorpaena porcus & 0.62 & 36 & 0.42 & & 1.10 & 0.39 \\
\hline Diplodus vulgaris & 0.13 & 33 & 0.03 & 0.13 & 0.15 & 0.25 \\
\hline Symphodus tinca & 0.71 & 33 & 0.79 & & 0.67 & 0.65 \\
\hline Octopus vulgaris & 0.52 & 31 & 0.40 & 0.93 & 0.51 & 0.64 \\
\hline Pagrus pagrus & 0.07 & 30 & 0.04 & 0.10 & 0.11 & 0.09 \\
\hline Sciaena umbra & 0.28 & 30 & 0.10 & 0.86 & 0.25 & 0.33 \\
\hline Chelidonichthys lastoviza & 0.14 & 30 & 0.03 & 0.42 & 0.18 & 0.18 \\
\hline Dicentrarchus labrax & 0.69 & 27 & 0.35 & 1.01 & 0.79 & 0.88 \\
\hline Zeus faber & 0.10 & 24 & 0.02 & 0.17 & 0.07 & 0.18 \\
\hline Mullus surmuletus & 0.10 & 20 & 0.03 & 0.49 & 0.06 & 0.10 \\
\hline Spondyliosoma cantharus & 0.06 & 20 & 0.03 & 0.09 & 0.06 & 0.09 \\
\hline Diplodus sargus & 0.08 & 19 & 0.10 & & 0.08 & 0.06 \\
\hline Scorpaena scrofa & 0.21 & 19 & 0.06 & 0.93 & 0.09 & 0.11 \\
\hline Serranus cabrilla & 0.03 & 16 & 0.01 & 0.11 & 0.01 & 0.04 \\
\hline Raja asterias & 0.45 & 14 & 0.23 & & 0.34 & 0.83 \\
\hline Solea senegalensis & 0.12 & 14 & 0.06 & & 0.16 & 0.20 \\
\hline Diplodus puntazzo & 0.06 & 13 & 0.01 & 0.17 & 0.03 & 0.12 \\
\hline Lithognathus mormyrus & 0.13 & 11 & 0.25 & & 0.08 & 0.10 \\
\hline Palinurus elephas & 0.16 & 11 & 0.04 & 0.25 & 0.13 & 0.19 \\
\hline Phycis phycis & 0.05 & 10 & 0.02 & & & 0.08 \\
\hline Merluccius merluccius & 0.03 & 9 & 0.02 & & 0.06 & 0.05 \\
\hline Mullus barbatus & 0.03 & 9 & 0.01 & & 0.03 & 0.04 \\
\hline Solea solea & 0.05 & 7 & 0.05 & & 0.06 & 0.07 \\
\hline Conger conger & 0.60 & 6 & 0.24 & 0.92 & 0.20 & 1.03 \\
\hline Lophius piscatorius & 0.51 & 6 & 0.15 & & 0.40 & 1.32 \\
\hline Sarpa salpa & 0.24 & 6 & 0.33 & & & 0.14 \\
\hline Torpedo marmorata & 1.47 & 6 & 1.20 & & 2.30 & 0.07 \\
\hline Trachinus draco & 0.07 & 6 & 0.01 & & 0.03 & 0.12 \\
\hline Dactylopterus volitans & 0.20 & 4 & 0.18 & & & 0.21 \\
\hline Diplodus annularis & 0.07 & 4 & 0.07 & & & \\
\hline Lepidorhombus boscii & 0.02 & 4 & 0.01 & & & 0.03 \\
\hline Serranus scriba & 0.05 & 4 & & & 0.05 & \\
\hline Sphyraena sphyraena & 0.42 & 4 & & & 0.40 & 0.48 \\
\hline Balistes capriscus & 0.48 & 3 & & & & 0.48 \\
\hline Bothus podas podas & 0.01 & 3 & 0.00 & & 0.02 & \\
\hline Lepidotrigla cavillone & 0.01 & 3 & 0.01 & & 0.01 & \\
\hline Mugil cephalus & 0.34 & 3 & & & 0.28 & 0.40 \\
\hline Muraena helena & 0.28 & 3 & & & 0.23 & 0.32 \\
\hline Pagellus bellottii & 0.15 & 3 & 0.13 & & & 0.17 \\
\hline Scophthalmus maximus & 0.34 & 3 & & 0.54 & 0.13 & \\
\hline Squilla mantis & 0.00 & 3 & 0.00 & & & \\
\hline Trachinus araneus & 0.26 & 3 & 0.06 & 0.46 & & \\
\hline Argyrosomus regius & 0.08 & 1 & 0.08 & & & \\
\hline Euthynnus alletteratus & 0.19 & 1 & & & & 0.19 \\
\hline Homarus gammarus & 0.32 & 1 & & & 0.32 & \\
\hline Labrus merula & 0.14 & 1 & & & 0.14 & \\
\hline Loligo vulgaris & 0.14 & 1 & & & 0.14 & \\
\hline Microchirus ocellatus & 0.02 & 1 & & & 0.02 & \\
\hline Mustelus mustelus & 0.06 & 1 & 0.06 & & & \\
\hline Oblada melanura & 0.21 & 1 & & & & 0.21 \\
\hline Pagrus auriga & 0.09 & 1 & 0.09 & & & \\
\hline Trachurus trachurus & 0.01 & 1 & 0.01 & & & \\
\hline
\end{tabular}

the guarding net was carried out similarly, but without the random factor, as only one vessel was used; in this case, the linear mixed model reduces to classical ANOVA. The models were fitted with function lme of the R library nlme using the restricted maximum likelihood algorithm. The posterior difference in means for factors with more than two levels was tested by posthoc analysis using library lsmeans. The effect of the modification was assessed by calculating its magnitude $(1=$ no effect $)$ and its confidence interval (significant effect when the CI does not cross 0 ). The standardized number of discarded weight (ind./100 $\mathrm{m} \mathrm{h}$ ) was subject to a similar statistical analysis, adding the factor type of discard (D, K1 and K2).

The species composition of catches (commercial and discards fraction) was also assessed by means of descriptive multivariate analysis, comparing the species composition in the different treatments (control; lights; guarding net). PRIMER ${ }^{\circledR}$ (Clarke and Gorley 2006) routines were used to examine the ordination in 
Table 2. - Standardized catch in numbers (ind./100 $\mathrm{m} \mathrm{h}$ ) and frequency of occurrence of unwanted catches (non-commercial species or undersize/damaged specimens of commercial species).

\begin{tabular}{|c|c|c|c|c|c|c|}
\hline species & Frequency of occurrence $(\%)$ & ind./100 $\mathrm{m} \mathrm{h}$ & control & guarding net & green lights & white lights \\
\hline Holothuria sp. & 27 & 54.59 & 10.46 & 4.37 & 19.23 & 20.53 \\
\hline Pagellus acarne & 19 & 14.95 & 3.97 & 0.45 & 6.36 & 4.17 \\
\hline Raja asterias & 17 & 10.58 & 2.26 & 0.67 & 5.23 & 2.42 \\
\hline Sepia officinalis & 13 & 9.00 & 1.06 & 1.99 & 2.89 & 3.06 \\
\hline Torpedo marmorata & 13 & 5.91 & 1.38 & 0.32 & 1.86 & 2.35 \\
\hline Astropecten sp. & 12 & 8.67 & 0.95 & 0.67 & 3.47 & 4.24 \\
\hline Echinaster sepositus & 11 & 7.30 & 0.98 & 0.40 & 3.40 & 2.51 \\
\hline Dactylopterus volitans & 9 & 4.55 & 0.97 & 1.00 & 0.96 & 1.61 \\
\hline Dicentrarchus labrax & 7 & 9.30 & 0.84 & 0.40 & 5.61 & 2.45 \\
\hline Pagrus pagrus & 7 & 1.63 & 0.34 & 0.17 & 0.70 & 0.42 \\
\hline Pagellus erythrinus & 7 & 5.85 & 0.89 & 0.40 & 2.91 & 1.65 \\
\hline Chelidonichthys lastoviza & 7 & 2.46 & 0.24 & 1.40 & & 0.82 \\
\hline Mullus surmuletus & 6 & 3.19 & 0.36 & & 2.00 & 0.83 \\
\hline Aporrhais pespelecani & 6 & 5.93 & 0.71 & & 4.09 & 1.12 \\
\hline Paracentrotus lividus & 6 & 1.63 & 0.40 & & 0.95 & 0.29 \\
\hline Symphodus tinca & 5 & 3.58 & 0.48 & & 2.20 & 0.91 \\
\hline Diplodus vulgaris & 4 & 1.12 & 0.21 & 0.54 & 0.38 & \\
\hline Scorpaena porcus & 4 & 2.64 & & & 1.77 & 0.87 \\
\hline Sparus aurata & 4 & 1.50 & 0.23 & & 0.69 & 0.59 \\
\hline Spondyliosoma cantharus & 4 & 1.19 & 0.50 & 0.50 & & 0.50 \\
\hline Diplodus annularis & 3 & 3.04 & 2.04 & & 1.00 & \\
\hline Myliobatis aquila & 3 & 0.69 & 0.16 & & 0.20 & 0.33 \\
\hline Sarpa salpa & 3 & 4.33 & 3.32 & & 0.71 & 0.31 \\
\hline Bolinus brandaris & 2 & 3.90 & & & & 3.90 \\
\hline Dardanus arrosor & 2 & 1.93 & 0.88 & & 1.05 & \\
\hline Loligo vulgaris & 2 & 0.52 & 0.13 & & 0.20 & 0.19 \\
\hline Scorpaena notata & 2 & 4.28 & 1.89 & & 0.67 & 1.72 \\
\hline Dentex dentex & 2 & 0.58 & 0.05 & & 0.54 & \\
\hline Diplodus puntazzo & 2 & 0.56 & 0.06 & & 0.50 & \\
\hline Hexaplex trunculus & 2 & 6.23 & 2.57 & & 1.33 & 2.32 \\
\hline Lissa chiragra & 2 & 0.67 & 0.04 & & 0.50 & 0.14 \\
\hline Merluccius merluccius & 2 & 0.73 & 0.16 & 0.29 & 0.29 & \\
\hline Mustelus mustelus & 2 & 0.40 & 0.11 & & & 0.29 \\
\hline Octopus vulgaris & 2 & 1.26 & & & 0.67 & 0.60 \\
\hline Phycis phycis & 2 & 1.04 & & & 0.90 & 0.14 \\
\hline Sciaena umbra & 2 & 1.04 & & & & 1.04 \\
\hline Serranus cabrilla & 2 & 0.64 & 0.36 & & & 0.27 \\
\hline Zeus faber & 2 & 1.20 & & 0.40 & & 0.80 \\
\hline Apogon imberbis & 1 & 0.10 & 0.10 & & & \\
\hline Pagellus bellottii & 1 & 1.24 & & & 0.67 & 0.57 \\
\hline Scyliorhinus canicula & 1 & 0.15 & 0.15 & & & \\
\hline Torpedo torpedo & 1 & 0.40 & & 0.20 & & 0.20 \\
\hline Arbacia lixula & 1 & 0.19 & & 0.19 & & \\
\hline Bothus podas podas & 1 & 0.40 & & & 0.40 & \\
\hline Conger conger & 1 & 0.48 & 0.48 & & & \\
\hline Leucoraja naevus & 1 & 0.40 & & & 0.40 & \\
\hline Mullus barbatus & 1 & 0.04 & 0.04 & & & \\
\hline Oblada melanura & 1 & 0.52 & 0.52 & & & \\
\hline Solea senegalensis & 1 & 0.04 & 0.04 & & & \\
\hline Solea vulgaris & 1 & 0.05 & 0.05 & & & \\
\hline Synodus saurus & 1 & 0.29 & & & 0.29 & \\
\hline Uranoscopus scaber & 1 & 0.68 & & & & 0.68 \\
\hline
\end{tabular}

multivariate space using non-metric multidimensional scaling (nMDS). The significance of factors (treatment guarding net or lights against control) was tested by means of analysis of similarities (ANOSIM).

\section{RESULTS}

\section{Commercial species}

During the experiments, 61 species of commercial interest were caught (Table 1). The target species, cuttlefish, was present in all nets sampled, with a yield of $1.43 \mathrm{~kg} / 100 \mathrm{~m} \mathrm{~h}$ on average. Other important commercial species in the catch were different species of sparids (e.g. the pandora Pagellus erythrinus, the gilthead seabream Sparus aurata, the dentex Dentex dentex, the seabass Dicentrarchus labrax, the scorpion fish Scorpaena scrofa, the octopus Octopus vulgaris and, due to their individual weight though they were not frequent, the rays Torpedo marmorata and Raja asterias) (Table 1). The hermit crab Dardanus arrosor was very frequently caught; this species is locally commercialized as bait for hook and line fisheries, not for human consumption.

The number of taxa discarded was 53, including damaged or undersize specimens of commercial species that could not be commercialized because they were undersized or damaged (Tables 2 and 3). The unwanted catches of non-commercial species (mainly epifaunal in vertebrates) were dominated by sea cucumbers (Holothuria sp.) and seastars (Astropecten sp. and Echinaster sepositus). Within commercialized species, the main reason for discarding was damage (type "K1"), which was particularly important for five spe- 
Table 3. - Number of fishing operations in which the commercial species indicated would have been discarded and reason: D, undersize individuals; $\mathrm{K} 1$, damaged individuals that cannot be commercialized.

\begin{tabular}{lcc}
\hline Species & $\mathrm{D}$ & $\mathrm{K} 1$ \\
\hline Bolinus brandaris & 2 \\
Dentex dentex & 3 \\
Dicentrarchus labrax & 12 \\
Diplodus annularis & 4 \\
Diplodus puntazzo & 3 \\
Diplodus vulgaris & 7 \\
Loligo vulgaris & 4 \\
Merluccius merluccius & 3 \\
Mullus barbatus & 1 \\
Mullus surmuletus & 10 \\
Mustelus mustelus & 3 \\
Octopus vulgaris & 2 \\
Pagellus acarne & 14 \\
Pagellus bellottii & 1 & \\
Pagellus erythrinus & 17 & 10 \\
Phycis phycis & 2 & 3 \\
Sciaena umbra & 1 & 3 \\
Scorpaena notata & & 4 \\
Scorpaena porcus & 5 \\
Sepia officinalis & & 21 \\
Sparus aurata & & 7 \\
Spondyliosoma cantharus & & \\
\hline
\end{tabular}

cies: D. labrax, M. surmuletus, $P$. acarne, $P$. erythrinus and $S$. officinalis (Table 3). Only specimens of Pagellus acarne and P. bellottii were discarded because of small size (Table 3).

The standardized yield of commercial catch species was lowest in both weight and number in the control trammel net, whereas that of unwanted catches was lowest in trammel nets fitted with the guarding net and highest in the trammel nets with lights on the head rope (Table 4). By typology of unwanted catches, the control trammel net had the highest amount of undersize fish and green lights the lowest. In terms of unwanted catches of categories $\mathrm{K} 1$ and $\mathrm{K} 2$, the trammel nets with the guarding net always had the lowest amount of unwanted catches and green lights the highest.

As regards the commercial species with frequency of occurrence higher than $30 \%$, the yields due to the different net configurations were compared. The total commercial catch was $32 \%$ higher in the trammel nets with the guarding net than in the standard configuration (Fig. 2). This was due mainly to the increased catches of the target species Sepia officinalis (increase of 95\%), Octopus vulgaris and some sparids (Diplodus vulgaris, Dentex dentex and Pagellus erythrinus) (Fig. 2). Notably, the catch of the gastropods Bolinus brandaris and Hexaplex trunculus showed no difference, while the catches of Dardanus arrosor were significantly lower with the guarding net (Fig. 2, see also Supplementary Material, Fig. S1).

The yields of the most frequently caught commercial species were tested also for the effect of artificial lights (Fig. 3). Overall, the commercial catch was significantly higher (around 13\%) in the trammel nets with head rope lights, but no statistical differences were observed between green or white lights. This re-

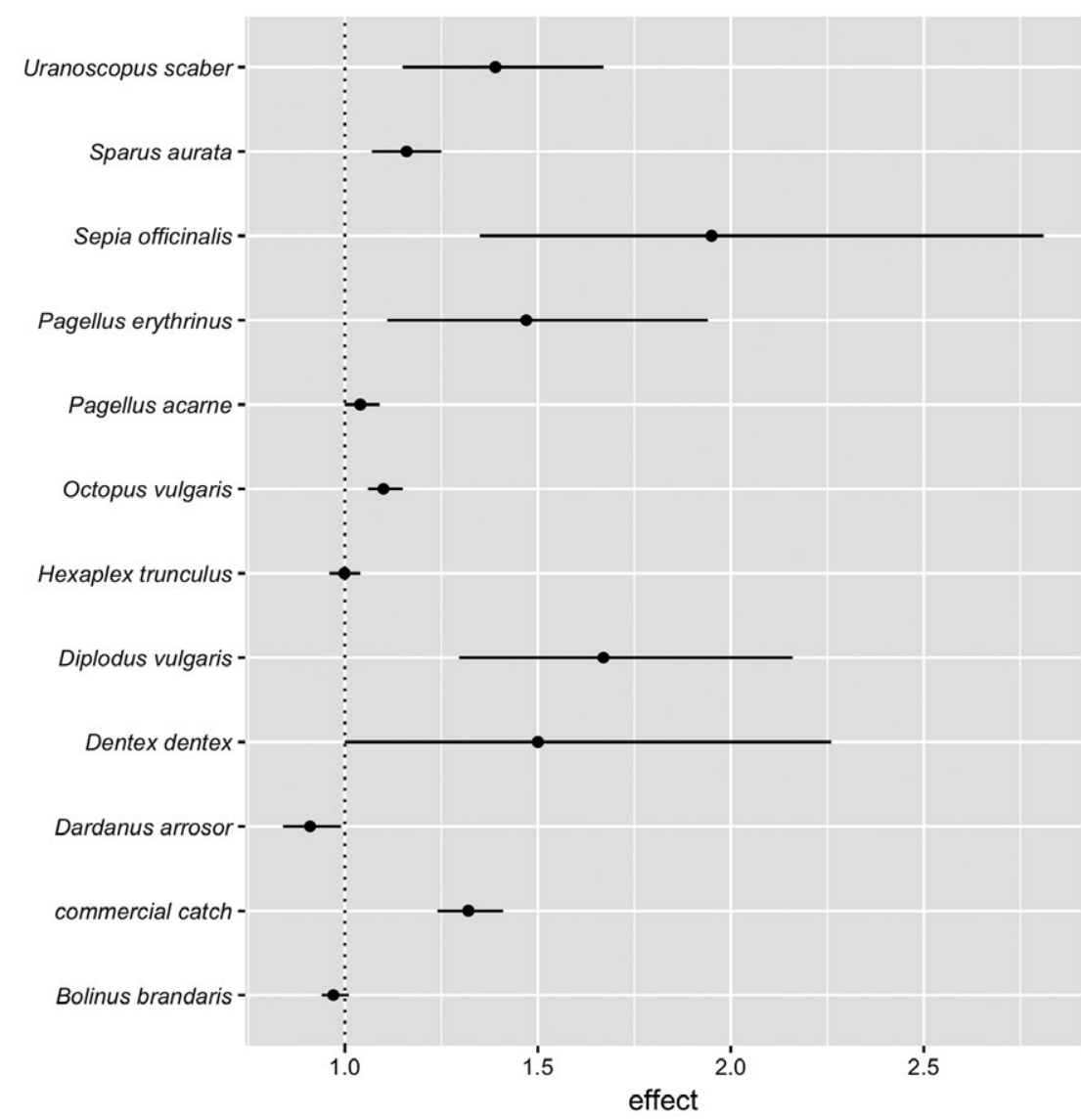

Fig. 2. - Relative measure of effect of the guarding net on the catches of the main commercial species in cuttlefish trammel nets (average and $95 \%$ confidence interval). A value of 1 corresponds to no effect (i.e. catches in $\mathrm{kg} / 100 \mathrm{~m}$ h of the modified net were not different from those of the standard net). 


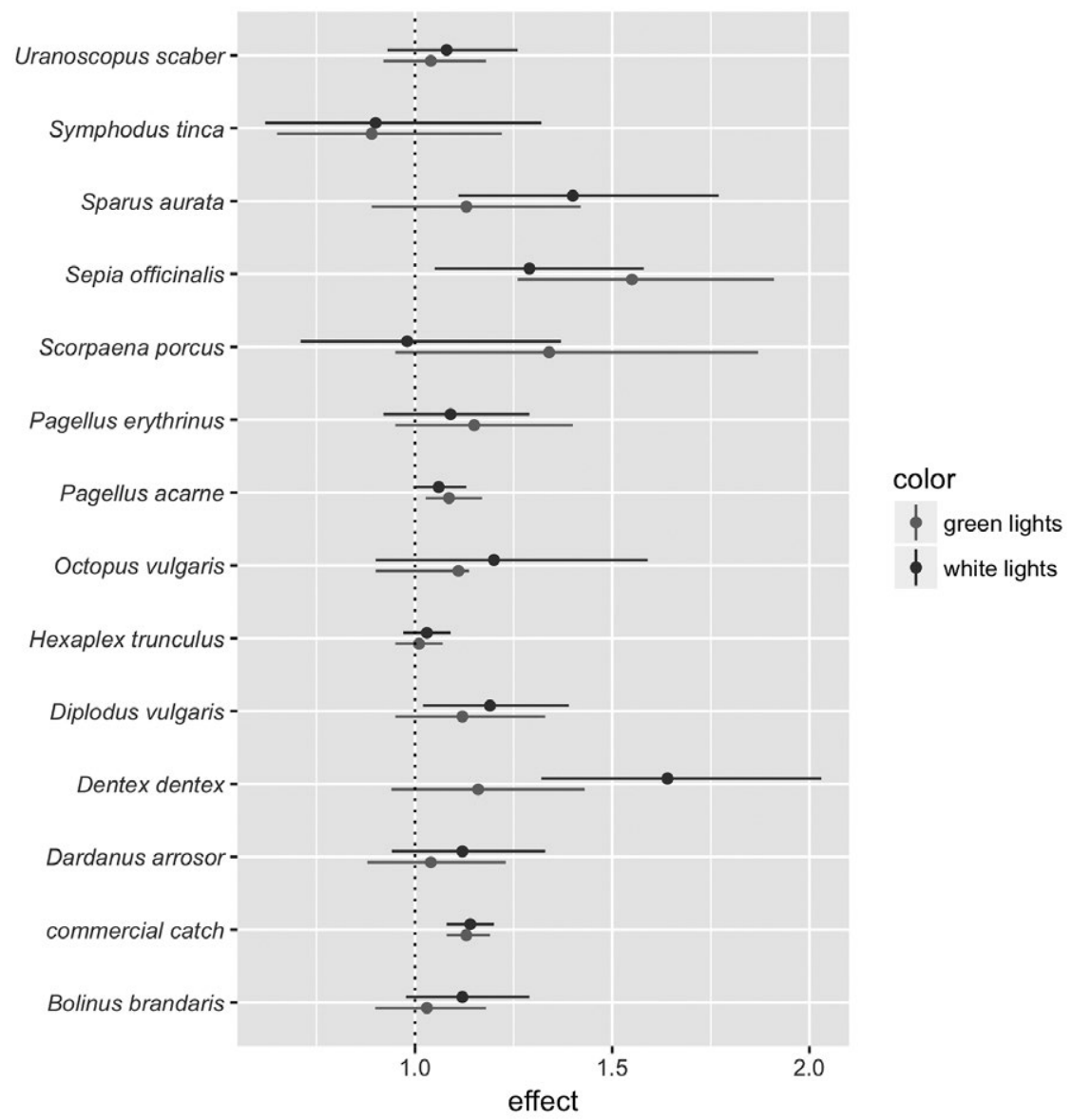

Fig. 3. - Relative measure of the effect of colour of lights mounted on the head rope on the catches of the main commercial species in cuttlefish trammel nets (average and $95 \%$ confidence interval). A value of 1 corresponds to no effect (i.e. catches in $\mathrm{kg} / 100 \mathrm{~m} \mathrm{~h}$ of the modified net were not different from those of the standard net).

sult was primarily due to the increased catches of the target species Sepia officinalis $37 \%$ higher combining both lights; no statistical difference between the two colours). As regards fishes, only the sparids Dentex dentex and Spaurus aurata showed a positive effect of lights, but in these two species the effect was significant for white light, not for green light. In other species, the effect of light was usually positive (except for Symphodus tinca), although not statistically significant (Fig. 3, see also Supplementary Material, Fig. S2).

\section{Unwanted catches}

The catch rates of unwanted catches were always significantly higher in the control nets (mean of 2.74 ind./100 $\mathrm{m} \mathrm{h}$ compared with 1.37 ind./100 m h; Figs 4 and 5, Table 4). The differences in unwanted catches between standard nets and nets with a guarding net varied depending on the reason of discarding, showing no interaction with the experimental treatment. A posthoc analysis showed that undersize unwanted catches (category "D") were not different between the control and modified configuration, while damaged individuals (K1) and non-commercial organisms (K2) were significantly lower in the modified configuration.

The amount of unwanted catches (ind./100 m h) was not significantly different in the nets modified with

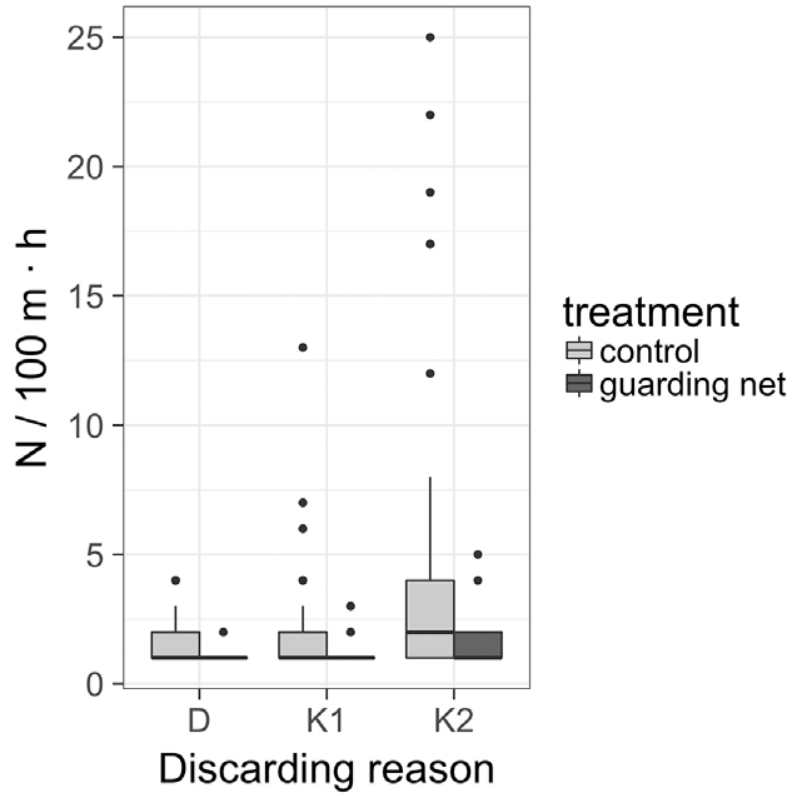

Fig. 4. - Abundance of unwanted catches in the guarding net configuration. (N/100 $\mathrm{m}$ h per species) compared with the control net. Discarding reasons: (D) undersize individuals falling under the Landings Obligation (Art. 15 of EU Reg. 1380/2013); (K1) damaged individuals of otherwise commercial species; (K2) non-commercial benthic invertebrates. 


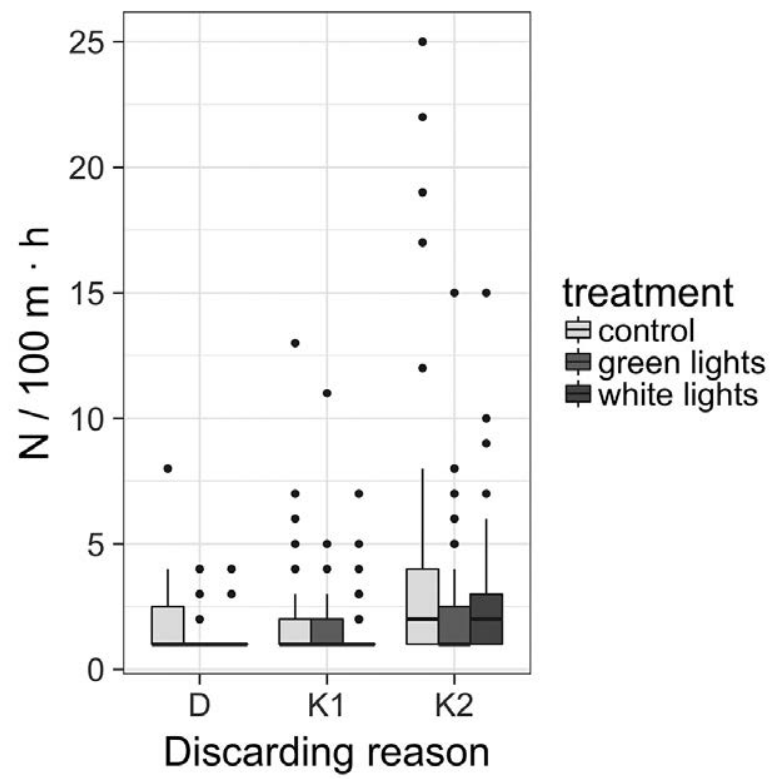

Fig. 5. - Abundance of unwanted catches in the configurations with artificial lights (each observation is a species). Discarding reasons: (D) undersize individuals falling under the Landings Obligation (Art. 15 of EU Reg. 1380/2013); (K1) damaged individuals of otherwise commercial species; (K2) non-commercial benthic invertebrates.

lights on the head rope compared with the control nets (Fig. 5). However, there were significant differences in the type of unwanted catches captured in the modified net $\left(\mathrm{p}=2.310^{-6}\right)$, with a significantly higher amount of category "K2" non-commercial invertebrates.

\section{Multivariate analysis}

The species composition of unwanted catches did not vary significantly according to treatment, either in the modified nets with a guarding net or in the nets fitted with lights (Fig. 6). The ANOSIM yielded a global correlation $\mathrm{r}=0.062$ for the comparison of faunal assemblages in the control against guarding net experiments $(\mathrm{p}=0.016)$. The ANOSIM results for the comparison of lights yielded a correlation $r=-0.004(p=0.68)$, with partial correlations lower than 0.01 in all cases and p-levels higher than 0.1 . In the commercial fraction, although the difference between the configuration with guarding net and the other nets was not significant,

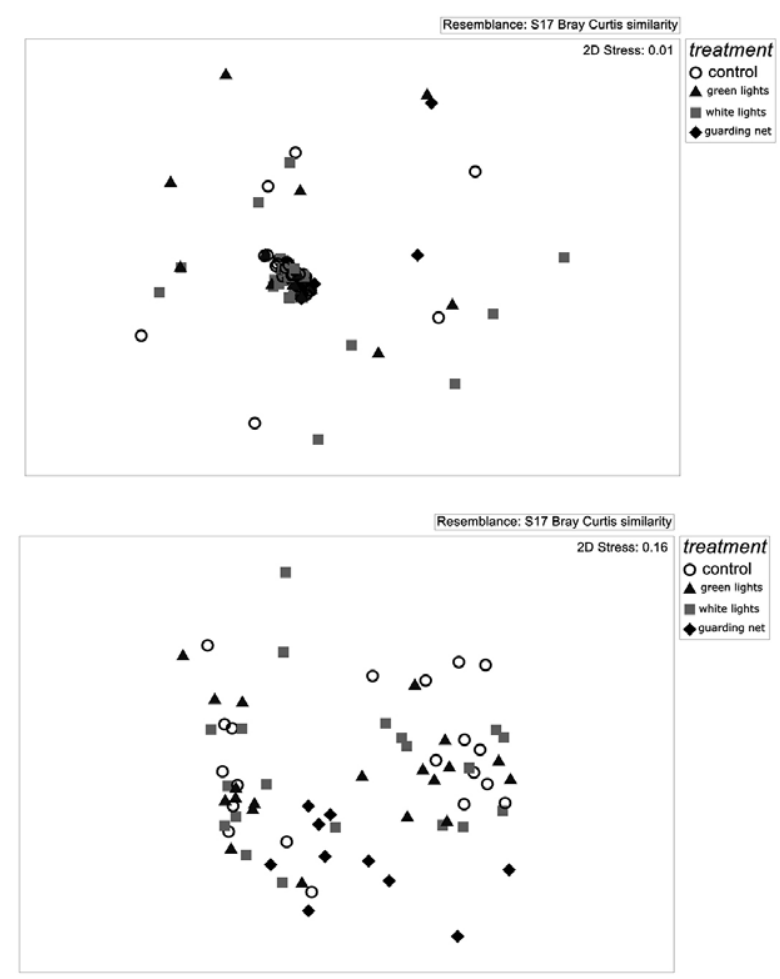

Fig. 6. - Non-metric multidimensional scaling (nMDS) of catch composition. TOP, species composition of unwanted catches; BOT-

TOM, species composition of the commercial fraction.

examining the species lists showed that the importance of fishes (especially sparids and seabass) was higher in the trammel nets with a guarding net than in the other configurations, where commercial invertebrates such as purple dye murex or commercial hermit crabs came second to the target species (cuttlefish) in abundance.

\section{DISCUSSION}

In our experimental trammel net deployment, unwanted catches of commercial species were mainly bitten or otherwise damaged individuals that could not be commercialized, frequently the target species Sepia officinalis and the fishes Pagellus acarne, $\mathrm{Pa}$ gellus erythrinus, Dicentrarchus labrax and Mullus surmuletus. Few specimens were considered unwanted catches because of their size (covered by Art. 15 of

Table 4. - Summary results of the trammel net experiments. UWC, unwanted catches that would normally be discarded. Discarding reasons: (D) Undersize individuals falling under the Landings Obligation (Art. 15 of EU Reg. 1380/2013); (K1) damaged individuals of otherwise commercial species; (K2) non-commercial benthic invertebrates. Asterisks represent the significance level of the comparison (larger or smaller catches) between the modified net and the control net (NS, not significant, * $\mathrm{p}=0.05$, ** $\mathrm{p}=0.01, * * * \mathrm{p}=0.001)$.

\begin{tabular}{|c|c|c|c|c|}
\hline & control trammel net & guarding net & green lights & white lights \\
\hline Commercial catch (ind./100 m h) & 208.81 & $272.28 * * *$ & $229.29 * *$ & $243.62 * *$ \\
\hline Commercial catch $(\mathrm{kg} / 100 \mathrm{~m} \mathrm{~h})$ & 49.11 & $64.04 * * *$ & $53.93 *$ & $57.30 * *$ \\
\hline Total UWC (ind./100 $\mathrm{m} \mathrm{h}$ ) & 40.39 & $19.81 * *$ & $69.52 \mathrm{NS}$ & $64.83 \mathrm{NS}$ \\
\hline Undersize UWC (D, ind./100 $\mathrm{m} \mathrm{h}$ ) & 8.44 & $7.77 \mathrm{NS}$ & $2.31 \mathrm{NS}$ & $7.15 \mathrm{NS}$ \\
\hline Damaged UWC (K1, ind./100 m h) & 11.24 & $5.69 *$ & $26.03 \mathrm{NS}$ & $20.39 \mathrm{NS}$ \\
\hline non-commercial UWC (K2, ind./100 m h) & 20.71 & $6.35 * *$ & $41.18 * *$ & $37.29 * *$ \\
\hline Percentage of UWC, in weight & $45 \%$ & $24 \%$ & $56 \%$ & $53 \%$ \\
\hline Percentage of D UWC, in weight & $9 \%$ & $9 \%$ & $2 \%$ & $6 \%$ \\
\hline Percentage of K1 UWC, in weight & $13 \%$ & $7 \%$ & $21 \%$ & $17 \%$ \\
\hline Percentage of K2 UWC, in weight & $23 \%$ & $8 \%$ & $33 \%$ & $31 \%$ \\
\hline
\end{tabular}


EU Reg. 1380/2013), both because the list of species caught by trammel net with minimum conservation reference size is limited and because the selectivity of the trammel nets used in south European fisheries is usually sufficient to guarantee a low percentage of undersize catches (Erzini et al. 2006). Only Pagellus acarne and $P$. bellottii were categorized as unwanted catches in more than half of the instances. Unwanted catches of non-commercial invertebrates were dominated by echinoderms (Holothuria sp., Astropecten sp. and Echinaster sepositus), as seen in other trammel net fisheries elsewhere (Gonçalves et al. 2008)

Our results show that discards can be significantly reduced in trammel net fisheries targeting cuttlefish through the simple adoption of a guarding net attached to the footrope of the trammel net. This modification has been tested successfully in other Mediterranean fisheries (Sartor et al. 2007, 2018, Metin et al. 2009). For instance, Sartor et al. (2007) showed that the unwanted by-catch in trammel nets targeting the caramote prawn (Penaeus kerathurus) was significantly reduced. However, in trammel nets targeting flatfish (different species of soles) the guarding net may unduly reduce the catches of the bottom-dwelling target species and may prove unacceptable to fishers (Szynaka et al. 2018). In our experiments with the guarding net on a trammel net used in the cuttlefish métier (spring), the commercial catches were significantly increased compared with the control net. Hence, although the reduction of unwanted by-catch is generally observed (Sartor et al. 2007, 2018, Metin et al. 2009, Szynaka et al. 2018), the effects of the guarding net on the catches of the target species must be considered on a métier by métier basis.

The types of unwanted by-catch that decreased significantly in the trammel nets with a guarding net were damaged individuals of commercial species and non-commercial organisms. This finding suggests that the main benefit of the guarding net is the reduction of predatory epifaunal invertebrates, which may damage the catches and also become entangled themselves. In addition to contributing to the conservation of epifaunal organisms (subject to a large amount of discarding: Gonçalves et al. 2008), the reduced catchability of these organisms helps reduce the sorting costs of trammel netters. The trammel nets with the guarding net modification did not affect the catch rates of commercial species by size (no difference in abundance of undersize commercial species). In addition to reducing unwanted by-catch, the catches of commercial species, particularly the target cuttlefish and some fishes, increased by $30 \%$. The combination of increased catches and reduced sorting costs suggests that the adoption of the guarding net can be easily accepted by industry if it is well demonstrated and disseminated.

In the experiments with commercially available lights, there was also a moderate (13\%) increase in commercial catches, mainly due to the increase in the catches of the cuttlefish. It is known that artificial light is attractive to cephalopods (Ben-Yami 1988), with well-documented examples in pelagic cephalopods (Inada and Arimoto 2007). In addition to cuttlefish, two sparids (dentex and gilthead seabream) showed attraction to white light (but not green), although the physiological basis for these results would require specific study (Arimoto et al. 2010). However, the deployments with artificial light also had a higher amount of unwanted catches than the control or guarding net configurations, perhaps because lights are more attractive to epifaunal invertebrates, as well as to cuttlefish. An effect of green light on the reduction of catches of undersize fish was appreciated (Table 4) but was not statistically significant.

In summary, though small-scale fisheries have relatively low amounts of unwanted catches, there is still room for improvement thanks to the adoption of relatively simple technological measures such as the guarding net tested here. The use of artificial lights to enhance selectivity in these fisheries operating by night in relatively shallow waters should be investigated further (Ben-Yami 1988), both in the laboratory and in the field, to understand the cues that can be manipulated to improve selectivity of trammel net fisheries, although this is probably a complex issue due to the different capture methods operating simultaneously in a trammel net (Erzini et al. 2006).

\section{ACKNOWLEDGEMENTS}

This study received funding from the European Commission's Horizon 2020 Research and Innovation Programme under Grant Agreement No. 634495 for the project Science, Technology and Society Initiative to Minimize Unwanted Catches in European Fisheries (MINOUW). The authors express their appreciation to the volunteer fishers who provided access to their fishing vessels during the experimental sampling, as well as to the technicians R. Trives, M.V. Trives and F. Parra for their assistance. We thank E. María Dolores and L. Bermúdez from the General Directorate of Agriculture and Fisheries of the Murcia Region for facilitating the field work.

\section{REFERENCES}

Arimoto T., Glass C.W., Zhang X. 2010. Fish vision and its role in fish capture. In: He P. (ed.), Behavior of marine fishes: capture processes and conservation challenges. Wiley-Blackwell, Ames, Iowa, pp. 25-40. https://doi.org/10.1002/9780813810966.ch2

Ben-Yami M. 1988. Attracting fish with light. FAO, Rome.

Clarke K.R., Gorley R.N. 2006. PRIMER v6: User Manual/Tutorial. PRIMER-E, Plymouth, $192 \mathrm{pp}$.

European Commission (EC). 2002. Communication from the Commission to the Council and the European Parliament on a Community Action Plan to reduce discards of fish (COM (2002) 656 final), $21 \mathrm{pp}$.

http://ec.europa.eu/transparency/regdoc/rep/1/2002/EN/12002-656-EN-F1-1.Pdf

European Commission (EC). 2013. European Council Regulation EC, 2013. No 1380/2013 of the European Parliament and of the Council of 11 December 2013 on the Common Fisheries Policy, amending Council Regulations EC No 1954/2003 and EC No 1224/2009 and repealing Council Regulations EC No 2371/2002 and EC No 639/2004 and Council Decision 2004/585/EC. Off. J. Europ. Union, L 354.

Erzini K., Gonçalves J.M.S., Bentes L., et al. 2006. Size selectivity of trammel nets in southern European small-scale fisheries. Fish. Res. 79: 183-201. https://doi.org/10.1016/j.fishres.2006.03.004 
Gonçalves J.M.S., Stergiou K.I., Hernando J.A., et al. 2007. Discards from experimental trammel nets in southern European small-scale fisheries. Fish. Res. 88: 5-14. https://doi.org/10.1016/j.fishres.2007.06.017

Gonçalves J.M.S., Bentes L., Coelho R., et al. 2008. Non-commercial invertebrate discards in an experimental trammel net fishery. Fish. Manag. Ecol. 15: 199-210. https://doi.org/10.1111/j.1365-2400.2008.00607.x

Griffiths R.C., Robles R., Coppola S.R., et al. 2007. Is there a future for artisanal fisheries in the western Mediterranean? Rome, FAO-COPEMED, 106 pp.

Guyader O. (co-ordinator). 2007. Small-scale coastal fisheries in Europe. Final Report of the project. European Commission FISH/2005/10.

Gullestad P., Blom G., Bakke G., et al. 2015. The "Discard Ban Package": Experiences in efforts to improve the exploitation patterns in Norwegian fisheries. Mar. Pol. 54: 1-9. https://doi.org/10.1016/j.marpol.2014.09.025

Inada H., Arimoto T. 2007. Trends on research and development of fishing light in Japan. J. Illum. Engng. Inst. Jpn. 91: 199-205.

Maynou F., Recasens L., Lombarte A. 2011. Fishing tactics dynamics of a Mediterranean small-scale coastal fishery. Aquat. Liv. Res. 24: 149-159. https://doi.org/10.1051/alr/2011131

Metin C., Gökçe G., Aydın İ., et al. 2009. Bycatch reduction in trammel net fishery for prawn (Melicertus kerathurus) by using guarding net in İzmir bay on Aegean coast of Turkey. Turk. J. Fish. Aquat. Sci. 9: 133-136.

Rossetti I., Vannucci A., Sartini M., et al. 2006. Pesca di mazzancolla, Penaeus kerathurus (Forsskål, 1775), con reti da posta presso la marineria artigianale di Viareggio (Mar Ligure sudorientale). Biol. Mar. Mediterr. 13: 284-285.

Sartor P., Silvestri R., Sbrana M., et al. 2007. Sperimentazione di accorgimenti tecnici per la riduzione dello scarto nella pesca con reti da posta lungo il litorale livornese. Biol. Mar. Mediterr. 14: 360-361.

Sartor P., Li Veli D., De Carlo F., et al. 2018. Reducing unwanted catches of trammel nets: experimental results of the "guarding net" in the caramote prawn, Penaeus kerathurus, small scale fishery of the Ligurian Sea (Western Mediterranean). Sci. Mar. 82S1: 131-140. https://doi.org/10.3989/scimar.04765.15B

Stergiou K.I., Moutopoulos D.K., Soriguer M.C., et al. 2006.Trammel net catch species composition, catch rates and métiers in southern European waters: A multivariate approach. Fish. Res. 79: $170-182$. https://doi.org/10.1016/j.fishres.2006.03.003

Szynaka MJ, Bentes L, Monteiro P, et al. 2018. Reduction of bycatch and discards in the Algarve small-scale coastal fishery using a monofilament trammel net rigged with a guarding net. Sci. Mar. 82S1: 121-129.

https://doi.org/10.3989/scimar.04734.16B

\section{SUPPLEMENTARY MATERIAL}

The following supplementary material is available through the online version of this article and at the following link:

http://scimar.icm.csic.es/scimar/supplm/sm04710esm.pdf

Fig. S1. - Effect of trammel net modification on main commercial species. Contrasts between standard trammel net and trammel net with a guarding net.

Fig. S2. - Effect of trammel net modification on the main commercial species. Contrast between standard trammel net and trammel et modified with head rope lights. 


\section{Reducing discards in trammel net fisheries with simple modifications based on a guarding net and artificial light: contributing to marine biodiversity conservation}

Pedro Martínez-Baños, Francesc Maynou

Supplementary material 


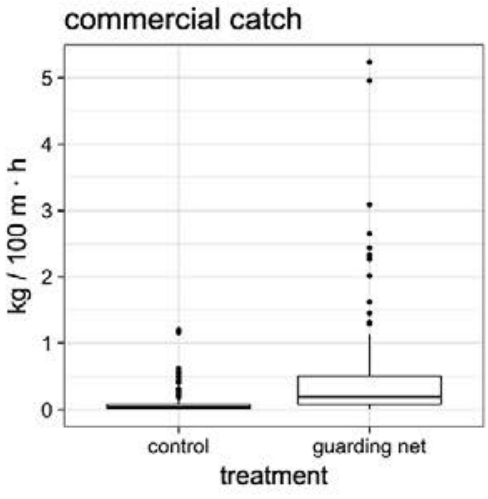

Dardanus arrosor

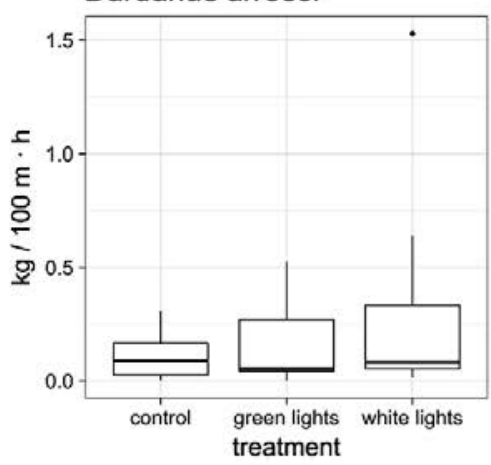

Uranoscopus scaber

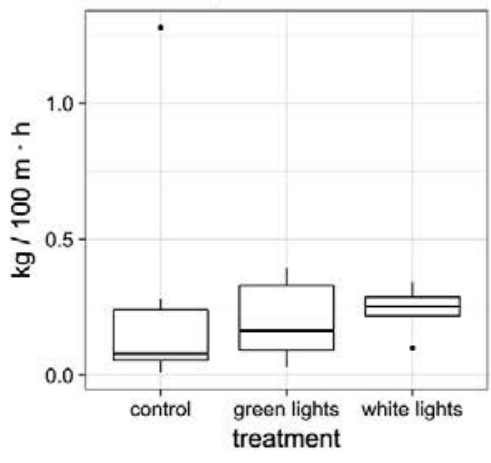

Pagellus erythrinus

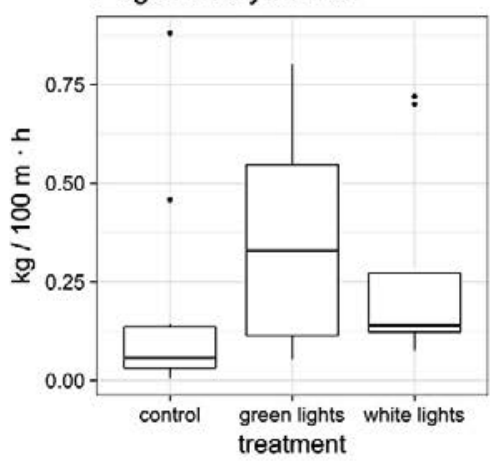

Sepia officinalis

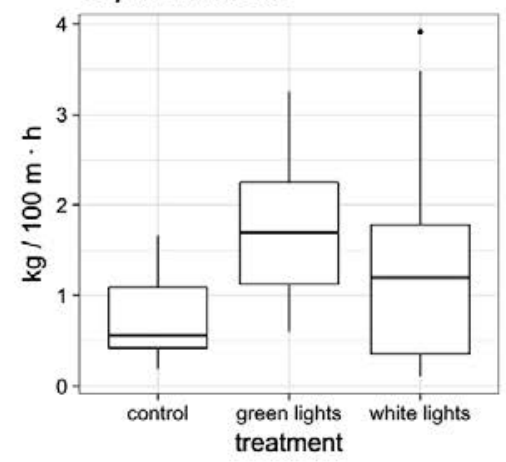

Bolinus brandaris
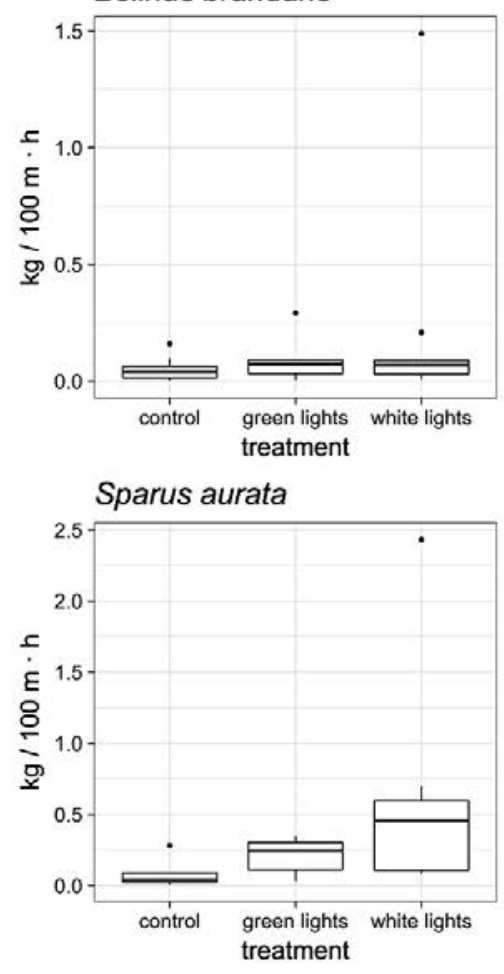

Pagellus acarne

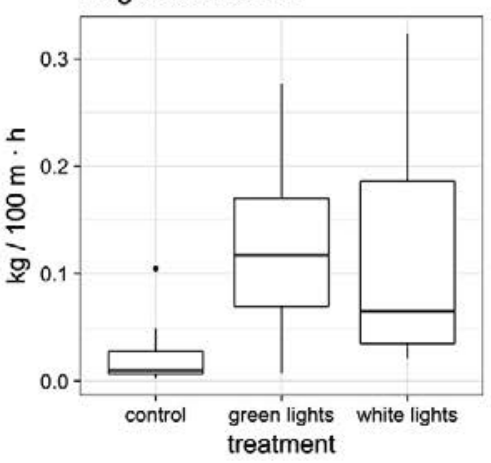

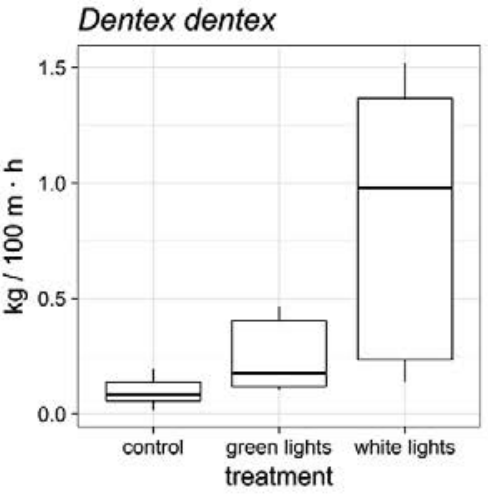

Octopus vulgaris

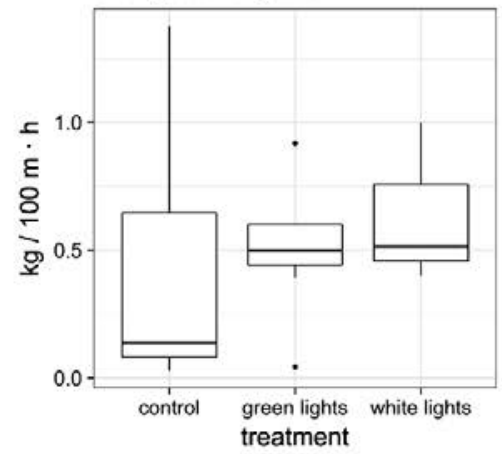

Hexaplex trunculus

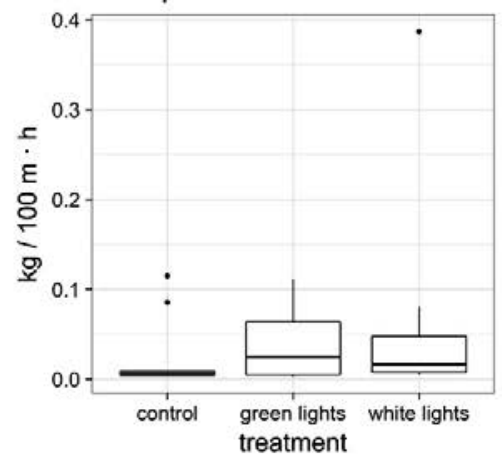

Diplodus vulgaris

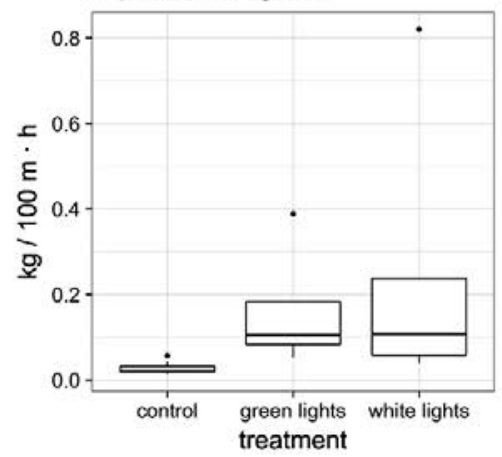

Fig. S1. - Effect of trammel net modification on main commercial species. Contrasts between standard trammel net and trammel net with a guarding net. 

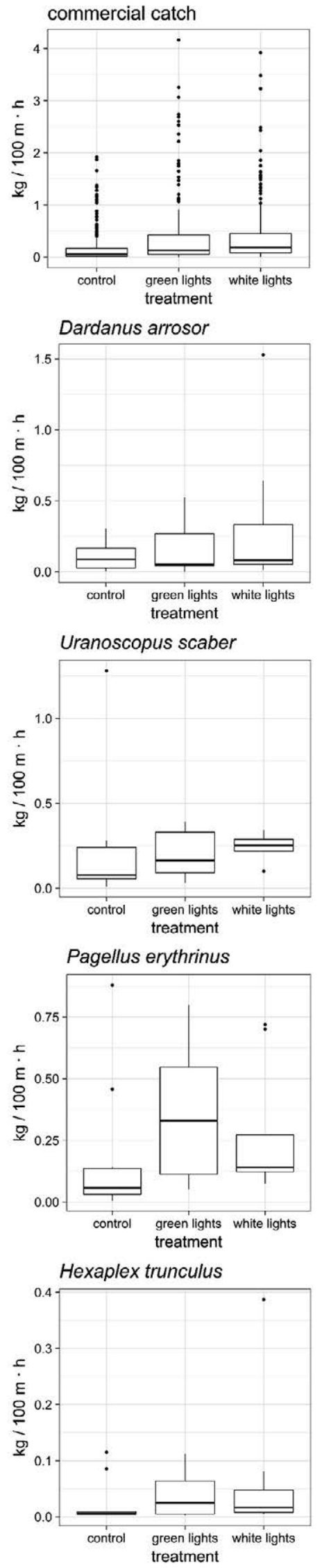
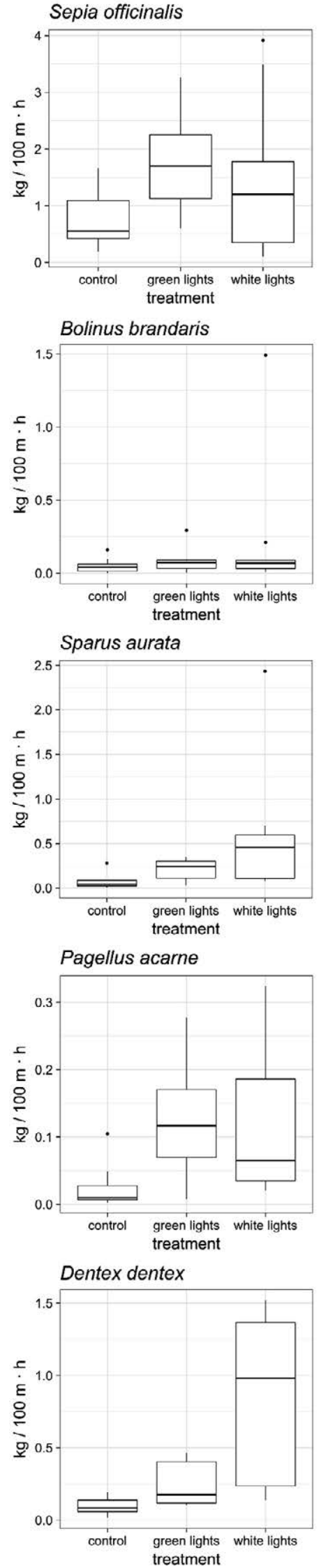
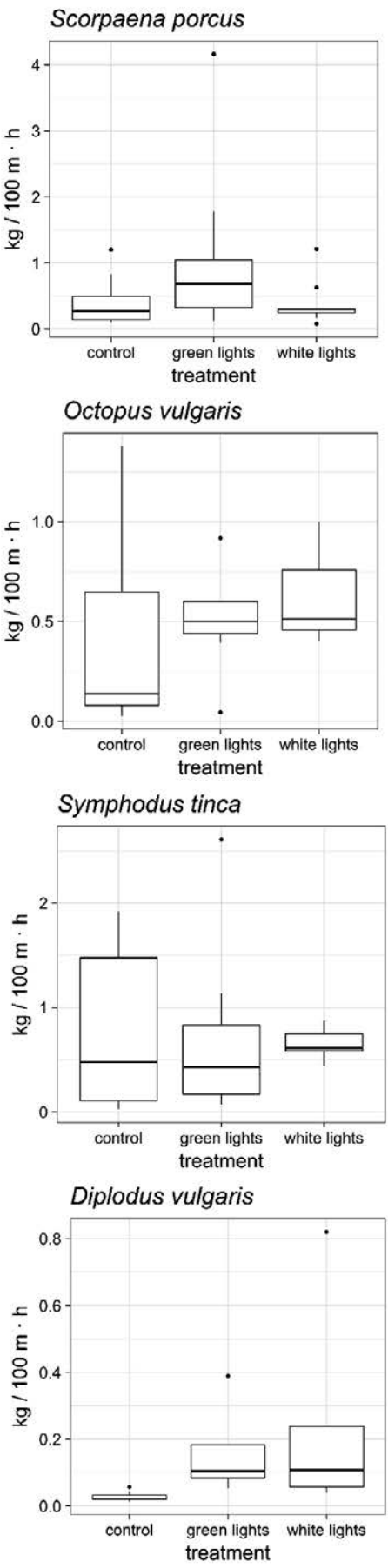

Fig. S2. - Effect of trammel net modification on the main commercial species. Contrast between standard trammel net and trammel et modified with head rope lights. 